\title{
Dynamic Approach for Diversification Effectiveness Evaluation of Berezovsky Company Town
}

\author{
Irine S. Antonova \\ Department of Management \\ National Research Tomsk Polytechnic University \\ Tomsk, Russia \\ antonovais@tpu.ru \\ Evgeny A. Pchelintsev \\ Department of Mathematical Analysis \\ National Research Tomsk State University \\ Tomsk, Russia \\ evgen-pch@yandex.ru
}

\author{
Danil D. Vavilov \\ Department of Management \\ National Research Tomsk Polytechnic University \\ Tomsk, Russia \\ CrystalUS@me.com
}

\begin{abstract}
Article represents the dynamic approach for diversification effectiveness assessment of company town Berezovsky that modifies the structure of it economy towards the multisectoral one. The effectiveness concept is considered as comparison between stated goals and opportunities to reach them. The authors evolved an autoregressive model with distributed lags of the first order type to describe the dependence between the share of the core industry in dispatched goods on its previous value and on the share of investments in core industry. The core industry of Berezovsky company town is mining operations including fossil fuels extraction and extraction of other minerals. The autoregressive model allows forecasting the share of dispatched goods in mining operations. Making the conclusion on opportunities to achieve the diversification targets let authors evaluate the diversification effectiveness.
\end{abstract}

Keywords-dynamic approach; company town; diversification; factors; effectiveness; autoregression model

\section{INTRODUCTION}

A company town in its natural state repeats the stages of life cycle of the town-forming enterprise with introduction, growth, maturity and decline. But in comparison with the enterprise the town has its own, wider responsibilities before community, small business and town-forming enterprise stakeholders. The company town life cycle tends to be longer and more sustainable than its town forming enterprise that takes to consider, evaluate and manage the risks of the enterprise declining. The recent research by Zemlyansky and Lamanov [1] defines the following operational models of Russian company towns development:

- Sustainable company town;

- Controlled shrinkage;

The reported study was supported by RFBR, research project No. 16-3600294 mol_a "The dynamic approach to effectiveness evaluation of diversification of a company town economy".

\section{- Industrial diversification.}

The authors [1] suppose the diversification scenario for company towns with upward dynamic of socio-economic wellbeing including town-forming enterprises with both upward and downward dynamic.

The concept of diversification is essentially elaborated for an enterprise being one of the generic [2] or growth strategies [3]. According to resource concept of the diversification [4] the most significant type of diversification is coherent, or relevant diversification. In contrast to incoherent diversification, coherent diversification strategy leads to the synergy effect of the core resource, technology or process: vertical or horizontal diversification. Incoherent diversification strategy allows entering to the brand new market with a new product for the current company using existing managing resources or experience. Nevertheless, both types of diversification aim at risk decrease and stability strengthen. The result of diversification can differ, but the most important research issue is empirical estimation of the coherence between diversification and performance.

The research by Asrarhaghighi, Rahhman, Sambasivan and Mohamed [5] systemized the results of different empirical evaluation of product diversification and performance defining the following scholars' results: positive, negative, nonsignificant and U-shaped relationships between product diversification and performance of the company. In this case, the type of relation between product diversification and performance can be considered as the tool of the diversification effectiveness showing the type of it.

Christiaensen, Weerdt, and Todo [6] have shown that the rural diversification lead to more inclusive growth patterns than metropolitization. The conclusion was based on the idea that majority of the poor will chose rural nonfarm economy instead of distant cities that assumes the development of the 
nonfarm rural settlements as well as secondary towns. Otherwise, Carson, Carson, and Henderson [7] identified that the diversification of remote towns caused by opportunity industries stimulated mainly the public services (health industry, education, and others). The labour growth in this case was basically due to newly resident and nonindigenous workers. The other factor of the labour and citizen wellbeing in company towns is corporate social responsibility that was studied in [8-11]. Nevertheless, the effectiveness of the diversification process is not completely studied.

In this paper we suggest to evaluate the influence of investments on production in core industry using correlation and regression methods. The mathematical model of relationships between core industry and investments will allow predicting the future structure of the company town economy and evaluate the opportunity to reach the stated diversification targets.

\section{COMPANY TOWN DIVERSIFICATION CONCEPT}

\section{A. Company Town Diversification}

A company town in this study is considered as the community with domination of single-industry in economy, social sphere and town budget. The single-industry is defined by the economy structure, social structure and financial structure of the town. Company town diversification in this case can be considered as the structure movement towards the stated purposes of company town strategic development with the aim to reduce the risk and reach sustainable development.

The movement of economic, social and financial structure of a company town should be considered in dynamics. The first step to this idea is company town criteria definition. In [9] the authors define that in the recent 7 years the Russian system of criteria has changed from town-forming enterprise status as a key criterion to the set of numerical criteria, including employment rate, industrial production share, and tax liabilities of the town-forming enterprise. And only since 2015 the criteria commenced to be regarded in dynamics: the employment rate of largest companies in the town should be over 20\% during last 5 years [12]. Dynamic measurement of the criteria allows eliminating short-term changes in the socioeconomic structure of the company town that are irrelevant to the diversification process. Next step of dynamic analysis of structural movements in a company town is research of diversification factors, indexes and efficiency.

\section{B. Diversification Effectiveness Factors of Company Towns}

Effectiveness is considered here as comparison between stated goals and opportunities to reach them. The study of 17 strategic documents for Kemerovo region company towns allows defining the following basic diversification targets by 2020:

1) In economic sphere:

- The share of core industry in total dispatched goods at the determined level: $11,8-60 \%$;

- The share of new and existing non-core industries in total volume of dispatched goods (or services): 30,5-
$75 \%$

- The share of small business in production: $18-31 \%$ or the growth in number of small business: by $13-15 \%$.

2) In social sphere:

- The rate of unemployment: 0,8-1,5\%;

- The level of average wages: 1,6-3,5 times growth for 10 years;

- The share of core industry employment rate: 7-12\%;

- The share of employment in small business: $42-45 \%$;

- The share of own incomes in local budget: 30-61,5\%.

The necessary criterion of the diversification is the growth of non-core industry share in employment, production or tax liabilities that cause the simultaneous reduction of the core industry share in employment, production or tax liabilities towards the town. The transition to the more sustainable group of socio-economic wellbeing refers to risk reduction of socioeconomic indicators, so it ensures the essential purpose of diversification to cut down the probability of deterioration in the core industry. On the basis of the conducted research we define the following diversification indexes that can be considered as dependent variable:

- Core/non-core industry employment rate;

- Core/non-core industry production share;

- Small business share in production and employment rate;

- Core/non-core industry tax liabilities share;

- Local budget own incomes share.

On the other hand, the following indexes can act as independent variables:

- Company town industrial index;

- The share of investments in the core/non-core industry or in non-industry economic activities;

- The share of investments in small business.

The correlation between dependent and independent variables will permit to evolve the model and forecast the future values of the diversification indexes. Finally, it will help to make a conclusion on diversification effectiveness by comparing the diversification targets and forecasting results.

\section{Berezovsky Company Towns}

Beresovsky has been included into the official list of Russian company towns since 2014 [13] and implements the diversification strategy of company town development. The official list currently consists of 319 company towns and supposes three groups according to the socio - economic risks:

- With the most difficult socio-economic state (including town-forming enterprise);

- With downside risks to the socio-economic state; 
- With sustainable socio-economic state.

Berezovsky places at the 136 position and is considered as the town with downside risks to the socio-economic state. The core industry of the town is mining operations that include the following economic activities:

- Fossil fuels extraction;

- Extraction of minerals except fossil fuel.

The proportion between dispatched goods in fossil fuels and other minerals during 2007-2014 was 95-99\% for fossil fuels and not more than $5 \%$ for the other minerals extraction. The same structure represents the investments in these activities. The core industry share of dispatched goods in Berezovsky company town economy for the period under review was $77-92 \%$ with a slight downward tendency.

Complex Investment Plan of Company Town Modernization [14] for Berezovsky stated the following diversification targets (Tabl. 1).

TABLE 1 BEREZOVSKY DIVERSIFICATION TARGETS IN DISPATCHED GOODS SHARE

\begin{tabular}{|c|c|c|c|}
\hline \multirow{2}{*}{ Indicator } & \multicolumn{3}{|c|}{ Diversification Targets } \\
\cline { 2 - 4 } & $\mathbf{2 0 1 1}$ & $\mathbf{2 0 1 4}$ & $\mathbf{2 0 2 0}$ \\
\hline Core industry dispatched goods share & $87,2 \%$ & $76,5 \%$ & $49 \%$ \\
\hline
\end{tabular}

The assessment of achieving the stated targets based on current and previous conditions in company town economics will allow concluding on the rate of current diversification effectiveness.

\section{METHODOLOGY}

The dynamic approach to evaluating the effectiveness of company town economy diversification considers the time aspect of target and varying factors. The duration of the considered time period depends on the available data and the moment of launching the diversification process. In this research we examine the period of 2007-2014. The object of the research is Berezovsky company town located in Kemerovo region in Russia. The subject of the research is the structural changes in the company town economy with mining operations as a core industry.

Analysis of the impact of investments share on the share of dispatched goods both in mining operations shows a linear relationship. The empirical correlation coefficient of Pearson equals 0,7685. To describe the dynamics of the share of dispatched goods in mining operations (time series $y$ ) depending on the share of investments in mining operations (time series $x$ ), it is proposed to build an autoregressive model with distributed lags of the first order type (1).

$$
y_{t} \square=a_{0}+a_{1} y_{t-1}+b_{0} x_{t}+\varepsilon_{\square}
$$

The model (1) was chosen due to the hypothesis for the dependence of the variable $y$ at the next period of time on its previous value. The model will allow to forecast the share of dispatched goods in mining operations in 2020 and to make a conclusion on achieving the diversification goal.

\section{RESUlTS AND DISCUSSIONS}

The model parameters was estimated using the ordinary least squares method that resulted in the following (2):

$$
a_{0}=0,3012 ; a_{1}=0,5638 \text { and } b_{0}=0,1992
$$

The parameter values less than unity, then we can conclude that the studied variables represent stationary time series. The determination coefficient for the constructed model $\mathrm{R}^{2}=0,91$. This indicates a high accuracy of selected equation model (3).

$\begin{array}{cc}y_{t} \square=0,3012+0,5638 y_{t-1}+0,1992 \\ x_{t}+\varepsilon_{\square} & \text { (3) }\end{array}$

The hypothesis of a serial correlation absence for the random deviations $\varepsilon$ was tested on Durbin - Watson criterion (DW). The calculated value of the criterion $\mathrm{DW}=1,9383$, it falls in the interval $(1,5 ; 2,5)$, so the residual autocorrelation is absent.

The normality of the distribution of residual components was tested by RS-criterion. The calculated value of the criterion $\mathrm{RS}=3,2213$ and it falls in the interval $(2,7 ; 3,7)$, therefore, we come to conclusion about a property of the normal distribution. Thus, the conducted analysis shows that the constructed model is adequate to the available data and can be used for prediction. The Fig. 1 confirms this statement.

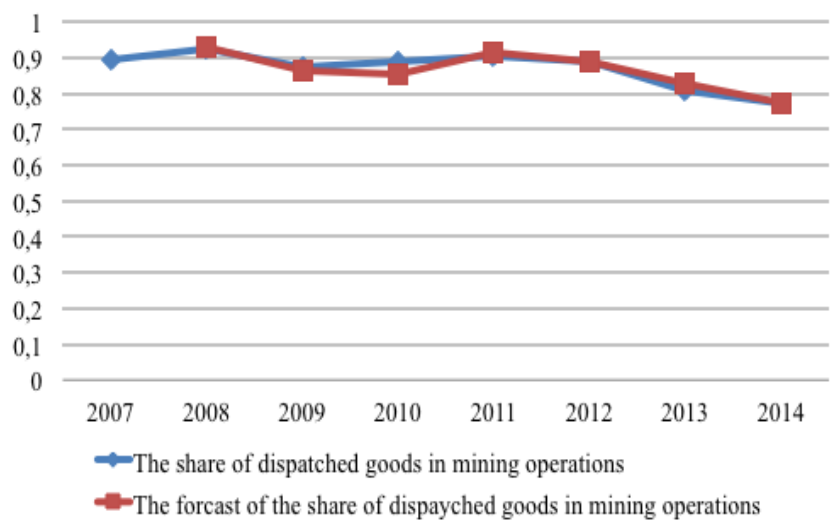

Fig. 1 Current and predicted share of dispatched goods in core industry in Berezovsky, Kemerovo region

To build a forecast for the value of dispatched goods in mining operations in 2015-2020, we supposed that the level of investments in mining operations have not changed since 2014 , and then assumed that it was equal to the average value in 2007-2014. The forecast for 2015-2020 shows that a low level of investments reduces the share of dispatched goods in the core industry and vice versa. The result is presented in Tabl. 2. 
TABLE 2 BEREZOVSKY DIVERSIFICATION GOALS IN DISPATCHED GOODS SHARE

\begin{tabular}{|c|c|c|}
\hline \multirow{2}{*}{ Year } & \multicolumn{2}{|c|}{ Core Industry Dispatched Goods Share } \\
\cline { 2 - 3 } & $\begin{array}{c}\text { Investments share } \\
(\mathbf{0 , 0 9 5 2 6 2 3 0 4})\end{array}$ & $\begin{array}{c}\text { Investments share } \\
(\mathbf{0 , 3 9 8 8 2 3 4 4 8})\end{array}$ \\
\hline 2015 & 0,75520805 & 0,81567041 \\
\hline 2016 & 0,74596198 & 0,84051064 \\
\hline 2017 & 0,74074941 & 0,85451458 \\
\hline 2018 & 0,73781076 & 0,86240946 \\
\hline 2019 & 0,73615407 & 0,86686028 \\
\hline 2020 & 0,73522009 & 0,86936948 \\
\hline
\end{tabular}

Comparison of predicted data against diversification targets allows making a conclusion about the low probability of the gaining the diversification goal stated in Complex Investment Plan of Company Town Modernization [15]. The conducted model shows that the current structure of the Berezovsky company town economy will not allow gaining the diversification target of $49 \%$ share of the core industry in dispatched goods by 2020. Considering the effectiveness concept as achieving the stated goals, we conclude that current results in diversification have low effectiveness.

\section{CONCLUSION}

The conducted study shows that in spite of the diversification efforts stated in Complex Investment Plan of Berezovsky Company Town Modernization the results of the diversification process have low influence on the economy structure changes. The elaborated model highlights the rigid structure of the Berezovsky company town economy based on the mining operations core industry. The studied economy shows high percentage of the core industry even in low investments share of it. This conclusion allows supposing more profound diversification activities to intensify this process otherwise the stated targets of the diversification will be unfulfilled.

\section{REFERENCES}

[1] D. Yu. Zemlyansky, S.V. Lamanov, "Scinarios of development for the mono-functional towns in Russia", Bulletin of Moscow university, vol.4, 2014, pp. 69-74.

[2] M. E. Porter, Competitive strategy: creating and sustaining superior performance. New York: 1985.

[3] D. A. Aaker, D. A. Adler, Developing business strategies, vol. 200. No. 1. New York: Wiley, 1984.

[4] D. J. Teece, R. Rumelt, G. Dosi, S. Winter, "Understanding corporate coherence: theory and evidence." Jour. of econ. beh. and org., vol. 23.1, pp. 1-30, January 1994.

[5] E. Asrarhaghighi, A. A. Rahhman, M. Sambasivan, Z. A. Mohamed, "Diversification strategy and performance studies: results, measures, and sampling design", Jour. of Adv. Man. Sc., vol. 1, no. 1, pp.12-18, March 2013

[6] L. Christiaensen, J. Weerdt, and Y. Todo, "Urbanization and poverty reduction: the role of rural diversification and secondary towns", Agric. Econ. ,vol. 44, N 4-5, 2013, pp. 435-447.

[7] D. A.Carson., D. B. Carson, A. Henderson, "Mobilising labour in remote'boom'towns for economic diversification: the case of Tennant Creek", North. Inst. Res. Br. Ser., vol. 5, 2014, pp. 1-14.

[8] O. P. Ivanova, I. S. Antonova, G. D. Antonov, Company towns development and investment attractiveness: Moscow, INFRA-M, 2016.

[9] I. S. Antonova, O. A. Negodina, D. D. Vavilov "Russian company town: creteria and diversification results", IBIMA 2015, pp. 2181-2187, November 2015.

[10] A. V. Khaperskaya, K. A. Bannova, S. Z. Musina, "The Influence of Corporate Social Responsibility Program on the Economic Mechanism as a Whole", ICEM 2015: Guilin, pp. 390-394, May 2015.

[11] D. Littlewood, “Cursed'communities? Corporate social responsibility (CSR), company towns and the mining industry in Namibia", Jour. of Bus. Eth., vol. 120 (1), pp. 39-63.

[12] Russian Government Resolution "Concerning distinguishing criteria of Russian Federation company towns and its classification depending on the risk of deterioration of their socio-economic wellbeing" of 29.07.2014. URL:

http://government.ru/media/files/41d4f68f6a0c7889b0a7.pdf

[13] The order of the Russian Federation Government "The list of company towns", July 29, 2014, N 1398-R. URL:

http://gov.garant.ru/document?id=70607138\&byPara=1\&sub=381

[14] Complex Investment Plan of Berezovsky Company Town Modernization, 2010. URL: http://monogorod.kemobl.ru/BEREZOVSKI/kipr1.pdf 